\title{
ONDARROA ETA LEGEDI BIKOIZTASUNA
}

\author{
Josu Etxaburu, Lorena Amutxastegi, \\ Ramón Castillo, Andrés Urrutia
}

Aurkibidea: 0. Lanaren HelburUa. 1. OndarRoa: KoKaPENA ETA HISTORIA. 2. BIZKAIKO BI LEGEDIAK. 2.1. Historia eta iritziak. 2.2. Ondarroako kasua. 2.2.1. Historia laburra. 2.2.2. Corpusaren aurkezpena eta kokapena. 2.2.3. Corpusaren ondorioak. 3. 1959. URTETIK AURRERA. 3.1. 1959. urteko Konpilazioa orokorrean hartuz. 3.2. Konpilazioa Ondarroari lotuta. 3.2.1. Hirigunearen zehaztea. 3.2.2. Baserriguneak zehaztea. 3.3. Berriatuaren anexioa eta beronen eragina. 3.4. Berriatuaren desanexioa eta beronen eragina. 4. EusKal HerRiKo Foru Zibil berRia (1992). ERREAlitate berRia. 5. ONDORIOAK. 6. BIBLIOGRAFIA.

\section{Lanaren helburua}

Bizkaian, Bizkaiko jaunek hiriak sortu aurretik, lurralde guztian ohitura berdinak genituen.

Hirien sorrerak, zuzenbide pribatuzko bi legedien agerketa ekarri zuen; honela, teorian hiri eta beronen lurretan Castillako legea zen aplikatu beharreko legedia eta baserrietan Forua. Lan honetan zehar Ondarroan azken ehun urtetan zer gertatu den argiago adierazten saiatuko gara nahiz eta ikusiko dugun bezala, alde baterako eta besterako iritziak izan.

Nonbaitetik hasi behar eta gure lanaren hipotesia hau izan da:

«Espainiako Kode zibila argitaratu zenetik (1889) eta aurretik ere, Ondarroako hirian (hirigunean) Castillako legea aplikatu izan da, baina Ondarroa inguratzen duen gune baserritarrean betidanik (nahiz eta teoriak beste gauza bat agindu) Forua erabili izan da.» 
Ondorengo orrialdeotan baieztapen hau ziurtatzen ahaleginduko gara, gure iritziz adierazgarri gerta daitezkeen hainbat baserriren azterketetan oinarrituz.

Lan honen garapenerako oinarrizko data bat izango da ardatza, hots, 1959. urtea, berton Bizkaiko Foru Konpilazioa argitaratzen baita.

Ezin ahaztu ere 1974ko maiatzean Ondarroako hiriari Berriatuako herrigunea atxikitu zitzaiola, 1983ko azaroaren 26an eman zelarik bion arteko bereizketa.

Egoera honek sortutako errealitate juridikoa ere ikutuko dugu, legedi ezberdinen jabe ziren lurraldeen artean emandako anexioa lehenengo eta desanexioa gero eman baitzen.

Zuzenbide pribatuaren aldetik Ondarroako lurretan (beste hiri bizkaitar batzuetan ere antzekorik gerta daitekeela uste dugu) behintzat begi bistako bikoiztasuna eman izan dela frogatu nahi dugu eta ondarrutar baserrien eskualdaketak, gehienetan ezkontideen arteko kapitulazioen bitartez, Foruan oinarrituta daudela.

Arrantzaleen arteko harremanak ohituretan oinarrituak eta aspaldidanikoak izanik, forupekoak izan daitezkeela iruditzen zaigu nahiz eta lan honetan atal hau sakondu ez.

Honela lege aldetiko azterketa honek, xx. mendean zer gertatu izan den Ondarroan erakutsiko digu.

\section{Ondarroa: Kokapena eta historia}

\section{Kokapena}

Bizkaiko Lea Artibai eskualdean kokaturiko herria dugu Ondarroa. Arrantzale herria, Bizkaiko kostaldeko gunerik garrantzitsuenetarikoa dugu, arrantzak beti bete baitu herri honetako oinarri ekonomikoa.

Aipatu behar, Ondarroako herria lur batzuren jabe ere izan zela, nolabaiteko gune baserritarra sortuz oinarriz arrantzalea den herri honen inguruan.

Aurrez esan bezala, lan honen helburua zuzenki loturik agertzen zaigu aipatu gune horrekin, berton ematen zen jokabide juridikoa aztertzea eta argitzea baita nahi duguna.

Lurralde menditsua, kareharrizko haitz izugarriak itsasorantz begira. Haran ugari. Kostaldea, izugarrizko amildegiek osatzen dute, horra hor Peña Fraile... e.a.

Barrurantz, Arrigorri, Santa Kurutz, Pertika, Kalamendi, Urzelai eta Mustutxuru mendiak ditugu. 
Ibai garrantzitsuena, Oiz menditik datorkigun Artibai. Ibai honek, bertako materialen gogortasunagatik, haran estu bat sortu du, badi txiki batetan itsasoratzen delarik. Berau, Ondarroako portua eraikitzeko aprobetxatua izan da.

Portu honetan bukatzen dute euren ibilbidea hainbat errekek, alegia, Saldu eta Amalloak.

\section{Historia}

Bizkaiko Anderea zen María Díaz de Harok sorturiko hiria dugu Ondarroa; «Carta Puebla» delakoa Lizarran, 1327an sinatu zuen. Honela, hiri berri honi, Berriatua elizateko lurrak erantsi zitzaizkion eta jaurerriko beste hiriak bezala, bere burua Logroñoko foruaz arautzeko eskubidea eman zitzaion.

Hiri sorkuntzarako eskubidea ere, Larako Juan Nuñez eta bere emaztea zen María andereak baieztatu zuten 1335.urtean. Bertan bere biztanleei «prebostada» eskubidea eman zien hamar urtetarako, hiria inguratuko zuen harresi bat eraikiz.

«Conoscida cosa sea a todos los homes que este previllejio vieren como jo doña María que fui del Infante don Juan, é Señora de Vizcaya fago merced a bos los pobladores de Ondarroa de estos fueros que aqui son escritos.»

Ondarroako mugak zeintzuk ziren azpimarratzen digu:

«En estos terminos han estos pobladores de Ondarroa por nonbre: de Amallogana fasta el Sel de Arranoeta, é dende a Mesla — conchaga, é dende á Hoar de suso, é dende a Arechenderraga, é dende á Legarreluz é dende a Aguila, é dende a la piedra ferpujarra, é dende al bado de Aleguren, é dende al pedregal de Chopitea, é dende a la punta de la pieza de Arechurra, é al rio de Mandioarraen fasta el puerto de Sansatan por do se parte con Lequeitio...»

Orduko Gorozika ere barru hartuz:

«...é mando que hayan por vecinos de la villa los mis labradores de Amallo, é demas doles á Gorocica con sus terminos, é con sus vienes con sus entradas, é con sus salidas, é demas doles lo que ha don Pedro Gonzalez de Aranzibia, é allende Vizcaya en la su fermandad en Ondarroa arededor dende, por que yo he dado Labradores en cambio a dicho don Pedro Gonzalez por el dicho heredamiento é que separe a todos los herederos dende de pagarlos». 
Alfonso XI.ak (orduko Bizkaiko jauna) Ondarroara sartu zenean, eginiko kalteak ordaindu asmoz, egurrezko zubi zaharretik trafikoa bideratzeko baimena eman zuen.

Gainera, Amallo Errenteria ere honen barne gelditzen zen. Ondorengo Jauntxoek ere, baieztatu egin zituzten herriko eskubide eta pribilejioak.

Enrique IV.ak ere, beste baimen eta mesede batzuk eman zizkion Ondarroako herriari, koroiari eskainiriko zerbitzuengatik; baita lagundu ere, 1463 ko sutean izandako galera handiengatik.

1351.ean, Ingalaterraren kontra aritu zen Bilbo, Plentzia eta Lekeitiorekin batera, Bayona eta Biarritz hartuak izan baitziren. Bakea 1353ko abenduaren 21ean sinatu zen Hondarrabian.

Herriko eliza, 1480an hasi zen eraikitzen. Badira baselizak ere: Gorozikako San Juan, Riberako Santa Clara eta Pietatea.

Arrantzale herria dela esan dugu aurrerago; XIX.mendeko hasieran, baziren alturako 18 ontzi, 8 ontzi txiki antxoa eta sardinetarako, 2 otarrainetarako eta 25 ontzi burdina garraiatzeko. Galizia, Portugal, Andaluzia eta Ingalaterrarekin bazuen komertziorik.

Felipe II.aren garaian, ia 50 ontzi eta ehun marinel zituen erregearen armadaren zerbitzuan. Komertzioa beherantz etorri zen baina XIX. menderarte Ondarroak jarraitu egin zuen ontzi eta belauntziak sortzen. Ildo honetan esan beharra dugu, Ondarroak hainbat herriri bere laguntza eskaini ziola.

Konbentzioko gudan, frantziar ejerzitoa Ondarroan sartu zen. Elizan sartu eta herriari sua eman zioten 1794. urtean hainbat etxe erreaz.

Herriko udaletxea, alkateak, bi agintarik, sindiko batek, bi diputatuk eta «personero» batek osatzen zuten.

Gernikako Batzar Nagusietan, hamaikagarren eserlekua betetzen zuen.

Beraz, Bizkaiko «hiri» bat dugu Ondarroa. Zuzenbide publikoaren ikuspegitik parte hartzen du Bizkaiko jaurerriaren bizimoduan. Zuzenbide pribatuaren aldetik, ostera, bere barnean bizi du legedi bikoiztasuna, gure kaleetan lege gaztelarra, gure baserrietan Bizkaiko Forua, beronek bi idazketa izan zituelarik: 1452an Foru Zaharra eta 1526an Foru Berria.

\section{Bizkaiko bi legediak}

\subsection{Historia eta iritziak}

Bigarren ataltxo honek, Bizkaiko zenbait herritan indarrean zen lege bikoiztasunaren berri ematea nahiko luke.

Hasteko esan behar, hiriak sortu aurretik, bazela Bizkaiko lurralde osoan usadioten oinarritutako legerik, ondoren berauek Foru Zaharrean 
(1452) bildu zirelarik. Foru Zahar hau 1526. urtean berriztu zen (Foru Berria).

Bizkaiko jaunek hiriak sortzeak, batasun honen etena ekarri zuen, bi legedi ezberdin agertuz:

a) Forala. Bizkaia osoan aplikagarria, hirietan izan ezik.

b) Castillako legedia. Hirietan aplikatzen zena.

Honela bada, Bizkaiko zuzenbidearen berezitasun nabari baten aurrean agertzen gara: legedi bikoiztasuna.

Adrian Celayaren ${ }^{1}$ liburuan, dena den, zailtzat jotzen du bata eta bestearen hedadura esparrua zehaztea, ez baita sarritan erraza izaten hiri eta beroni lot dakizkiokeen lurren definitzea.

Ezin ahaztu ere elizateak edota hiriak elkartzen/bereizten zirenean, bikoiztasun hau agerian geratzen zela.

Bi legedi izateak, besteak beste, hiri eta elizateen arteko eztabaidak ekarri zituen, 1487ko ekainaren 22an jasotako akordioa izanik adierazpen adierazkorrena.

Akordio honek, bi ardatz zituen:

a) Hiriak Bizkaiarengandik bereiztuko ziren.

b) Hiriek Batzar Nagusietara ordezkorik ez zuten bidaliko.

Bion arteko adiskidetza 1630.urtean sinatutako «Escritura de Unión y Concordia» delakoaren bitartez eman zen.

Dokumentu hau zeharo garrantzitsua dugu legedi zibilaren ikuspuntutik, hirien esku geratzen baita eskatzea baserri eta beroni dagozkion lurrei aplikatzen zaien legedia bera, eurei ere aplikatzea.

Idazki honek bere bigarren atalean zera dio:

«...y que si alguna de dichas villas y ciudad quisiera dejar alguna ley de las que han tenido y tomar otras de las que usa el Señorío pidiendo al Señorío en Junta General haga las leyes que se pidieron conformándose con las del Fuero, lo que haya de hacer...»

Beraz, Batzar Nagusietara zuzendutako eskabidea onartu ondoren, hiriek legediz aldatzea posible zuten. Bide hau lau hirik hartu zuten: Elorriok (1712), Bermeok (1734) Otxandianok (1819) eta Villarok (1825).

Laurotatik batek bakarrik, Bermeok, eskatu zuen legediaren aldakuntza bere osotasunean aplikatzea auzo batean; besteek, ondorengotza Foru zuzenbidearen ildotik bideratzea eskatu zuten bitartean.

1 Celaya Ibarra, A. Comentarios al Código Civil y Compilaciones Forales. Tomo XXVI (Compilación de Vizcaya y Alava). Edit. Revista de Derecho Privado (26-61. orr.). 
Gauzok honela, xx.mendeak zuzenbide pribatu arloan Espainiako Kode Orokorraren berrikuntza ekarri zuen eta ondorenez Espainiako Kode Zibilaren eraskina idatzi beharra, Bizkaia eta Arabako kasuetan, oinarrizko legearen 6. artikuluak zioenez:

Art. 6. ${ }^{\circ}$ El Gobierno, oyendo a la Comisión de Códigos, presentará a las Cortes en uno o varios proyectos de ley, los apéndices del Código Civil, en los que se contengan las instituciones forales que conviene conservar en cada una de las provincias o territorios donde hoy existen.

Bizkaiko Kodifikazioaz jardun zuen komisio berezi bateko partaide eta eragilea izan zen Don Carlos de la Plaza y Salazarrek arazo honi buruz bere ikuspuntua honela adierazi zuen: Bizkaiko lurraldeetan, hirietan izan ezik, Foru zuzenbidea aplikatu behar zen eta aipatu hirietan Kode zibila beharko litzateke nagusi mugarte osoan.

Honako herriotan Kode zibila soilik aplikatu beharko litzateke: Durango, Ermua, Lanestosa, Lekeitio, Ondarroa, Plentzia, Portugalete, Valmaseda eta Orduña ziren.

Beste honakoetan bi legediak bakoitza bere esparruan nagusi gisa eta ez bata bestearen osagai gisa: Munitibar eta Gerrikaitzeko elizatean, Santurtzin, Zeberioko haranean eta Bermeo, Bilbo, Elorrio, Gernika eta Luno, Larrabetzua, Markina, Ugao, Mungia, Otxandiano, Errigoiti eta Areatzako hirietan.

Hiriotan legedi bata edo bestea aplikatzeko momentuan jarraitu beharreko arau batzuk ere eskaintzen ditu De la Plazak².

Esan behar, jurista honek egindako lan eta ikuspuntua, komisioak bereganatu zuela osotasunean.

Ikuspuntu hau ez dator bat, ordea, urte batzuk geroago Rodrigo Jadok 1923.urtean ${ }^{3}$ argitaratutako liburuan agertzen den Don Marcelo de Lecanda legegizonak (Gernikako hirian lanean aritu zenak) adierazitakoaz:

«...las villas, generalmente con muy pocas excepciones, se rigen en la parte urbana por el derecho común y las anteiglesias y parte rural de las villas por el Derecho Foral».

Hemen agertzen zaigu bada lehen arazoa, Plaza jaunak ez baitu hirigunea eta hiri-landen arteko desberdintasunik egiten lehen multzoko he-

2 De la Plaza y Salazar, C. Actas de la Comisión Especial de Codificación de Vizcaya. Ejemplar ofrecido al I. Colegio de Abogados de Bilbao, 1899.

3 Jado Y Ventades, R. «Derecho Civil de Vizcaya». Comentarios a las leyes del Fuero de Vizcaya. 2. ${ }^{\text {a }}$ edición. Bilbao, 1923. (144. orr.). 
rrietan. Beronentzat Forua baserri eta beroni atxikitzen zaizkion lurrez gain, Bizkaiko jaunaren lurrak izaki errenta ordaintzen zizkietenetan (casas censuarios) aplikatzen zen soilik.

Rodrigo Jadok, De la Plazak egindako sailkapena oraindik gehiago zehaztu nahian, beste kontzeptu berri bat sartzen du hirien aldetik: Bizkaiko lurraldeetan sorturiko hiriak diren edota lur hauetatik kanpo sortuak izanik orain Bizkaikoak izatea.

Bigarren kasu honetakoak Valmaseda, Lanestosa, Otxandiano, Orduña eta Durango ditugu, berauetan Castillako legea aplikazioa goitik beherako zelarik, sortu ziren lurretan Bizkaikoetan agertzen den bikoiztasunik ez baitzen.

Jadok (1923) eskaintzen dituen adierazpenak kontutan izanik ${ }^{4}$, De la Plazak egindako bereizketa teorian hala aplikatu behar bazen ere, praktika beste gauza bat agintzen ari zela konturatzen gara.

Ez dirudi hiriei zegokien lurretan zeuden baserri eta ohiturek, lur hauetatik kanpo zeudenen artean desberdintasunik zegoenik, hau dela eta, ez dirudi logikoegia batak legedi bat izatea besteak beste desberdin bat duen artean, eta ez dirudi ere bidezkoa elizate batek Foruak galtzea hiri batekin elkartzen denean, batez ere 1630ko «Escritura de Unión y Concordia» delakoak bere lehen artikulan (8. orrialdean aipatua) adierazitakoaz bat bagatoz.

Adrian Celayak adierazi legez, ez da posible esatea Kode Zibila hirietako udal mugarte osoan eta gainontzeko lurretan Forua aplikatzen zela, hainbat hiritan eta elizateren batean ere bi legediak baitzeuden indarrean.

Bikoiztasun honen aurrean entzun eta adierazi ziren irtenbideak era batekoak eta bestekoak izan dira mende honetan zehar autoreen artean:

\section{Allende Salazarrek:}

-Forua Bizkaiko lurralde osora hedatzea planteatzen du, berau baita (bere iritziz) garapen ekonomikorako legedi egokiena.

—Forua Arabako probintziara hedatzea ere planteatzen du. (1918an Oñatiko Euskal Ikasketa Kongresuak gauza bera mantendu zuen).

2. Gregorio Balpardak:

-Forua baserriko legea izan behar da.

—Forua Bizkaia osoan aplikatu beharko litzateke, baina baserrian soilik.

3. Angulo Lagunak-Garcia Royok:

—-Legedi bikoiztasunaren alde agertzen dira.

4 Ibidem, 14. orr. 
-Zuzenbideak ezin ditu arazoak desagertarazi legedi bat baztertuz eta bai ordea arazoak konpontzen lagundu.

4. Carlos de la Plaza-Rodrigo Jado:

-Bizkaia osorako gustora hartuko lukete legedi bakarra, baina arazoak ikusirik, herri bakoitzarentzat bat bakarra lortzea dute helburua.

\subsection{Ondarroako kasua}

\subsubsection{Historia laburra}

Bizkaiko bi legediei buruzko historia eta iritziak ezagutu ondoren, Ondarroari dagokion errealitateari lotuko gatzaizkio.

Hiri honek, arrantzalea izanik, beti izan du baserri gune garrantzitsua eta gune hau da, hain zuzen ere, bete betean jaso dezakeena legedi bikoiztasuna.

Hainbat baserriren historian, lege aldetik, gertatu izan denak, hasieran aipatutako hipotesia ziurtatu edota ezeztatuko duelakoan gaude.

\subsubsection{Corpusaren aurkezpena eta kokapena}

Orokorrean aztertu dugun egoera zehaztasunean oinarrituko dugu oraingoan; beraz, Ondarroaren gune baserritarrean aplikatzen den legediaz jardungo dugu.

Zenbait datu eskuartean izan genitzan, lagin gisa aztertu nahi dugun esparruan, hainbat urtetan familia berekoak (edota nahiz eta eurena izan ez, alokatua izan dena mendeetan zehar) izan diren baserrien jabetza erregistro historiak irakurriz aritu izan gara.

Aukeratutako baserriak honako hauek izan dira:

a) Asterrika inguruan kokatuak:

-Antigua

- Arteta

- Buenos Aires

—Ikaita zar

b) Errenteria inguruan kokatuak:

-Patrokua

- Allenda 
c) Gorozika ingurukoak:

-Bizkua

- Munabe

d) Miloi ingurukoa:

—Eizmendi

Ikus daitekeenez, hiru gune garrantzitsu definitu ditugu lehenik eta behin (nahiz eta garai batean Ondarroako lurretan kokatuta zegoen Eizmendi baserria ere agertu): Asterrika, Gorozika eta Errenteria.

Zergatik hauek eta ez beste batzuk izan daiteke erantzun beharreko lehen galdera. Erantzuna berehalakoa da, auzo hauetako baserrion kokapen geografikoa da guretzat interesgarria, lurraldez Ondarroa izanik, teorikoki hirigunearen legedi berberaz koarautu behar baitziren.

Baieztapen hau da hain zuzen ere, guk zalantzan jartzen duguna, gure herrian emandako praktika juridikoak beste zerbait ere adierazten baitu.

Oso kontutan hartzekoak izango dira (ondorengo azterketan antzeko errealitateak ager daitezkeelako) Foruen aplikazioak sortzen dituen bitartekoak.

Laburki azalduz, hiru nagusienetarikoak aipatuko ditugu:

a) Tronkalitatea

-Familia ondasunekin lotua agertzen zaigu.

— Jabetza mugatua da, baserriaren jarraipena ziurtatzeko.

- Baserriaren jabetza, familiaren inguruan, familiaren zerbitzuan eta familiaren erabilpenerako da.

-Ondasunak, familiaren inguruan ulertzen dira eta momentuko titularraren gainetik daude.

b) Oinordekotza

-Ondasun horien jabeak, oinordekoren bat aukeratu eta bestelako oinordeak bazter ditzake.

c) Kapitulazioak

- Honen barruan, «ezkontz kontratuak» deituak gehienbat, zeintzutan aurrerantzean senar-emazteen arteko eta gurasoekiko harreman ekonomiko-juridikoak zehazten diren.

Zuzenki nahiz zeharka, aipatu eran jokatzeak, baserriaren mantentzea ekarri du gaur egunerarte.

Honela bada, aukeratutako baserri bakoitzaren historia txiki bat osatzen zehazten ahaleginduko gara, ondorengo orrialdeetan eskualdaketak, baztertzeak, ezkontz kontratuak etabar nola eman diren azalduz. 


\subsubsection{Corpusaren ondorioak}

\begin{tabular}{|c|c|c|c|c|c|c|}
\hline \multirow[b]{2}{*}{ Baserria } & \multicolumn{6}{|c|}{ Lehen eskualdaketa } \\
\hline & Data & $\begin{array}{c}\text { Ezkontz } \\
\text { kontratua }\end{array}$ & Dohaintza & Testamentua & Legedia & Bazterketa \\
\hline $\begin{array}{l}\text { Eizmendi } \\
\text { Chacartegi }\end{array}$ & $\begin{array}{l}1902 \\
7-12\end{array}$ & $\mathrm{Ez}$ & Bai & - & Forala & Bai \\
\hline
\end{tabular}

\begin{tabular}{|c|c|c|c|c|c|}
\hline \multicolumn{5}{|c|}{ Bigarren eskualdaketa } \\
\hline Data & $\begin{array}{c}\text { Ezkontz } \\
\text { kontratua }\end{array}$ & Dohaintza & Testamentua & Legedia & Bazterketa \\
\hline $\begin{array}{c}1949 \\
11-14\end{array}$ & $\mathrm{Ez}$ & - & Bai & Zibila & Ez \\
\hline
\end{tabular}

\begin{tabular}{|c|c|c|c|c|c|}
\hline \multicolumn{5}{|c|}{ Hirugarren eskualdaketa } \\
\hline Data & $\begin{array}{c}\text { Ezkontz } \\
\text { kontratua }\end{array}$ & Dohaintza & Testamentua & Legedia & Bazterketa \\
\hline 1963 & Ez & Bai & - & Forala & Bai \\
$2-22$ & & - & & \\
\hline
\end{tabular}

\begin{tabular}{|r|c|c|c|c|c|c|}
\hline \multirow{2}{*}{ Baserria } & \multicolumn{5}{|c|}{ Lehen eskualdaketa } \\
\cline { 2 - 7 } & Data & $\begin{array}{c}\text { Ezkontz } \\
\text { kontratua }\end{array}$ & Dohaintza & Testamentua & Legedia & Bazterketa \\
\hline \multirow{2}{*}{ Arteta } & 1888 & Bai & Bai & - & Forala & Ez \\
\hline
\end{tabular}

\begin{tabular}{|c|c|c|c|c|c|}
\hline \multicolumn{5}{|c|}{ Bigarren eskualdaketa } \\
\hline Data & $\begin{array}{c}\text { Ezkontz } \\
\text { kontratua }\end{array}$ & Dohaintza & Testamentua & Legedia & Bazterketa \\
\hline 1926 & Bai & Bai & - & Forala & Bai \\
$7-14$ & & - & & \\
\hline
\end{tabular}

\begin{tabular}{|c|c|c|c|c|c|}
\hline \multicolumn{5}{|c|}{ Hirugarren eskualdaketa } \\
\hline Data & $\begin{array}{c}\text { Ezkontz } \\
\text { kontratua }\end{array}$ & Dohaintza & Testamentua & Legedia & Bazterketa \\
\hline $\begin{array}{r}1935 \\
6-19\end{array}$ & Ez & - & Bai & Zibila & Ez \\
\hline
\end{tabular}

\# Oinordekoari behartasun batzuk ezartzen dizkio. 


\begin{tabular}{|c|c|c|c|c|c|c|}
\hline \multirow{2}{*}{ Baserria } & \multicolumn{6}{|c|}{ Lehen eskualdaketa } \\
\cline { 2 - 7 } & Data & $\begin{array}{c}\text { Ezkontz } \\
\text { kontratua }\end{array}$ & Dohaintza & Testamentua & Legedia & Bazterketa \\
\hline Antigua & $\begin{array}{c}1903 \\
6-4\end{array}$ & Bai & Bai & - & Forala & Ez \\
\hline
\end{tabular}

\begin{tabular}{|c|c|c|c|c|c|}
\hline \multicolumn{5}{|c|}{ Bigarren eskualdaketa } \\
\hline Data & $\begin{array}{c}\text { Ezkontz } \\
\text { kontratua }\end{array}$ & Dohaintza & Testamentua & Legedia & Bazterketa \\
\hline $\begin{array}{c}1933 \\
4-28\end{array}$ & Ez & - & Bai & Forala & Bai \\
\hline
\end{tabular}

\begin{tabular}{|c|c|c|c|c|c|}
\hline \multicolumn{5}{|c|}{ Hirugarren eskualdaketa } \\
\hline Data & $\begin{array}{c}\text { Ezkontz } \\
\text { kontratua }\end{array}$ & Dohaintza & Testamentua & Legedia & Bazterketa \\
\hline- & - & - & - & - & - \\
\hline
\end{tabular}

\begin{tabular}{|l|c|c|c|c|c|c|}
\hline \multirow{2}{*}{ Baserria } & \multicolumn{5}{|c|}{ Lehen eskualdaketa } \\
\cline { 2 - 7 } & Data & $\begin{array}{c}\text { Ezkontz } \\
\text { kontratua }\end{array}$ & Dohaintza & Testamentua & Legedia & Bazterketa \\
\hline $\begin{array}{l}\text { Buenos } \\
\text { Aires }\end{array}$ & $\begin{array}{c}1935 \\
12-18\end{array}$ & Bai & Bai & - & Forala & Bai \\
\hline
\end{tabular}

\begin{tabular}{|c|c|c|c|c|c|}
\hline \multicolumn{5}{|c|}{ Bigarren eskualdaketa } \\
\hline Data & $\begin{array}{c}\text { Ezkontz } \\
\text { kontratua }\end{array}$ & Dohaintza & Testamentua & Legedia & Bazterketa \\
\hline 1989 & Ez & Bai & - & Zibila & - \\
$5-12$ & & - & & \\
\hline
\end{tabular}

\begin{tabular}{|c|c|c|c|c|c|}
\hline \multicolumn{5}{|c|}{ Hirugarren eskualdaketa } \\
\hline Data & $\begin{array}{c}\text { Ezkontz } \\
\text { kontratua }\end{array}$ & Dohaintza & Testamentua & Legedia & Bazterketa \\
\hline- & - & - & - & - & - \\
\hline
\end{tabular}




\begin{tabular}{|r|c|c|c|c|c|c|}
\hline \multirow{2}{*}{ Baserria } & \multicolumn{5}{|c|}{ Lehen eskualdaketa } \\
\cline { 2 - 7 } & Data & $\begin{array}{c}\text { Ezkontz } \\
\text { kontratua }\end{array}$ & Dohaintza & Testamentua & Legedia & Bazterketa \\
\hline \multirow{2}{*}{$\begin{array}{c}1871 \\
\text { Ikaitazar }\end{array}$} & $7-12$ & Bai & Bai & - & Forala & Ez \\
\hline
\end{tabular}

\begin{tabular}{|c|c|c|c|c|c|}
\hline \multicolumn{5}{|c|}{ Bigarren eskualdaketa } \\
\hline Data & $\begin{array}{c}\text { Ezkontz } \\
\text { kontratua }\end{array}$ & Dohaintza & Testamentua & Legedia & Bazterketa \\
\hline $\begin{array}{c}1909 \\
10-15\end{array}$ & Bai & Bai & - & Forala & Ez \\
\hline
\end{tabular}

\begin{tabular}{|c|c|c|c|c|c|}
\hline \multicolumn{5}{|c|}{ Hirugarren eskualdaketa } \\
\hline Data & $\begin{array}{c}\text { Ezkontz } \\
\text { kontratua }\end{array}$ & Dohaintza & Testamentua & Legedia & Bazterketa \\
\hline $\begin{array}{c}1949 \\
1-12\end{array}$ & Bai & Bai & - & Forala & Bai \\
\hline
\end{tabular}

\& Emaztea hiltzerakoan (1935), banaketarako legedi forala erabiltzen da.

\begin{tabular}{|c|c|c|c|c|c|c|}
\hline \multirow{2}{*}{ Baserria } & \multicolumn{6}{|c|}{ Lehen eskualdaketa } \\
\cline { 2 - 7 } & Data & $\begin{array}{c}\text { Ezkontz } \\
\text { kontratua }\end{array}$ & Dohaintza & Testamentua & Legedia & Bazterketa \\
\hline Patrokua & $\begin{array}{c}1968 \\
2-7\end{array}$ & Ez & Ez & Bai & Forala & Bai \\
\hline
\end{tabular}

\begin{tabular}{|c|c|c|c|c|c|}
\hline \multicolumn{5}{|c|}{ Bigarren eskualdaketa } \\
\hline Data & $\begin{array}{c}\text { Ezkontz } \\
\text { kontratua }\end{array}$ & Dohaintza & Testamentua & Legedia & Bazterketa \\
\hline- & - & - & - & - & - \\
\hline
\end{tabular}

\begin{tabular}{|c|c|c|c|c|c|}
\hline \multicolumn{5}{|c|}{ Hirugarren eskualdaketa } \\
\hline Data & $\begin{array}{c}\text { Ezkontz } \\
\text { kontratua }\end{array}$ & Dohaintza & Testamentua & Legedia & Bazterketa \\
\hline- & - & - & - & - & - \\
\hline
\end{tabular}




\begin{tabular}{|c|c|c|c|c|c|c|}
\hline \multirow{2}{*}{ Baserria } & \multicolumn{7}{|c|}{ Lehen eskualdaketa } \\
\cline { 2 - 7 } & Data & $\begin{array}{c}\text { Ezkontz } \\
\text { kontratua }\end{array}$ & Dohaintza & Testamentua & Legedia & Bazterketa \\
\hline \multirow{2}{*}{ Beazkoa } & $\begin{array}{c}1868 \\
12-31\end{array}$ & Bai & Ez & Bai & Forala & Bai \\
\hline
\end{tabular}

\begin{tabular}{|c|c|c|c|c|c|}
\hline \multicolumn{5}{|c|}{ Bigarren eskualdaketa } \\
\hline Data & $\begin{array}{c}\text { Ezkontz } \\
\text { kontratua }\end{array}$ & Dohaintza & Testamentua & Legedia & Bazterketa \\
\hline $\begin{array}{c}1880 \\
6-18\end{array}$ & Bai & Bai & - & Forala & Bai \\
\hline
\end{tabular}

\begin{tabular}{|c|c|c|c|c|c|}
\hline \multicolumn{5}{|c|}{ Hirugarren eskualdaketa } \\
\hline Data & $\begin{array}{c}\text { Ezkontz } \\
\text { kontratua }\end{array}$ & Dohaintza & Testamentua & Legedia & Bazterketa \\
\hline 1915 & Bai & Bai & - & Forala & Ez \\
$2-11$ & Ez & - & & \\
\hline
\end{tabular}

\begin{tabular}{|c|c|c|c|c|c|}
\hline \multicolumn{5}{|c|}{ Laugarren eskualdaketa } \\
\hline Data & $\begin{array}{c}\text { Ezkontz } \\
\text { kontratua }\end{array}$ & Dohaintza & Testamentua & Legedia & Bazterketa \\
\hline $\begin{array}{c}1962 \\
5-2\end{array}$ & Ez & - & Bai & Forala & Bai \\
\hline
\end{tabular}

\begin{tabular}{|r|c|c|c|c|c|c|}
\hline \multirow{2}{*}{ Baserria } & \multicolumn{7}{|c|}{ Lehen eskualdaketa } \\
\cline { 2 - 7 } & Data & $\begin{array}{c}\text { Ezkontz } \\
\text { kontratua }\end{array}$ & Dohaintza & Testamentua & Legedia & Bazterketa \\
\hline \multirow{2}{*}{ Allenda } & $\begin{array}{c}1962 \\
3-22\end{array}$ & Bai & Bai & - & Forala & Ez \\
\hline
\end{tabular}

\begin{tabular}{|c|c|c|c|c|c|}
\hline \multicolumn{5}{|c|}{ Bigarren eskualdaketa } \\
\hline Data & $\begin{array}{c}\text { Ezkontz } \\
\text { kontratua }\end{array}$ & Dohaintza & Testamentua & Legedia & Bazterketa \\
\hline- & - & - & - & - & - \\
\hline
\end{tabular}

\begin{tabular}{|c|c|c|c|c|c|}
\hline \multicolumn{6}{|c|}{ Hirugarren eskualdaketa } \\
\hline Data & $\begin{array}{c}\text { Ezkontz } \\
\text { kontratua }\end{array}$ & Dohaintza & Testamentua & Legedia & Bazterketa \\
\hline- & - & - & - & - & - \\
\hline
\end{tabular}

* Aurreko ezkontzako semeek bere anaiordeari eskaintzen diokiote baserriarekiko dituzten eskubideak. 


\begin{tabular}{|r|c|c|c|c|c|c|}
\hline \multirow{2}{*}{ Baserria } & \multicolumn{5}{|c|}{ Lehen eskualdaketa } \\
\cline { 2 - 7 } & Data & $\begin{array}{c}\text { Ezkontz } \\
\text { kontratua }\end{array}$ & Dohaintza & Testamentua & Legedia & Bazterketa \\
\hline Munabe & $\begin{array}{c}1913 \\
6-17\end{array}$ & Ez & - & Bai & Zibila & Ez \\
\hline
\end{tabular}

\begin{tabular}{|c|c|c|c|c|c|}
\hline \multicolumn{5}{|c|}{ Bigarren eskualdaketa } \\
\hline Data & $\begin{array}{c}\text { Ezkontz } \\
\text { kontratua }\end{array}$ & Dohaintza & Testamentua & Legedia & Bazterketa \\
\hline $\begin{array}{c}1949 \\
9-4\end{array}$ & Bai & - & Bai & Forala & Bai \\
\hline
\end{tabular}

\begin{tabular}{|c|c|c|c|c|c|}
\hline \multicolumn{5}{|c|}{ Hirugarren eskualdaketa } \\
\hline Data & $\begin{array}{c}\text { Ezkontz } \\
\text { kontratua }\end{array}$ & Dohaintza & Testamentua & Legedia & Bazterketa \\
\hline $\begin{array}{l}1984 \\
5-16\end{array}$ & Ez & - & Bai & Zibila & Ez \\
\hline
\end{tabular}

\# Oinordekoari behartasun batzuk ezartzen dizkio.

\section{Zenbait datu adierazgarri}

Aztertutako eskualdaketak

Foralpean emandakoak

-Ezkontz kontratuak

—Ezkontz kontratugabeak

Legedi zibilpean emandakoak
22

$17(\% 77,27)$

$12(\% 70,58)$

$5(\% 29,41)$

$5(\% 22,72)$

\section{Datuak auzoka (Eskualdaketetan erabilitako Legediaz)}

\begin{tabular}{|c|c|c|c|c|c|}
\hline \multirow{2}{*}{ Auzoak } & \multirow{2}{*}{$\begin{array}{c}\text { Eskualdaketa } \\
\text { kopurua }\end{array}$} & \multicolumn{4}{|c|}{ Erabilitako legedia } \\
\cline { 3 - 6 } & & \multicolumn{2}{|c|}{ Forala } & \multicolumn{2}{|c|}{ Zibila } \\
\cline { 3 - 6 } & & Kop. & $\%$ & Kop. & $\%$ \\
\hline Asterrika & 10 & 8 & 80 & 2 & 20 \\
\hline Gorozika & 8 & 6 & 75 & 2 & 25 \\
\hline Errenteria & 1 & 1 & 100 & - & - \\
\hline Eizmendi & 3 & 2 & 66,6 & 1 & 33,3 \\
\hline
\end{tabular}


Datuak auzoka (Eskualdaketetan bideaz)

\begin{tabular}{|c|c|c|c|c|}
\hline \multirow{2}{*}{ Auzoak } & \multicolumn{4}{|c|}{ Eskualdaketen bidea } \\
\cline { 2 - 5 } & \multicolumn{2}{|c|}{ Dohaintza } & \multicolumn{2}{c|}{ Testamentu } \\
\cline { 2 - 5 } & Kop. & $\%$ & Kop. & $\%$ \\
\hline Asterrika & 8 & 61,5 & 2 & 22,2 \\
\hline Gorozika & 3 & 23 & 5 & 55,5 \\
\hline Errenteria & - & & 1 & 11,1 \\
\hline Eizmendi & 2 & 15,3 & 1 & 11,1 \\
\hline
\end{tabular}

\section{Bazterketa}

\begin{tabular}{|c|c|c|c|}
\hline \multicolumn{4}{|c|}{ Bazterketa } \\
oinordekoa izendatzerakoan \\
\hline \multicolumn{2}{|c|}{$\begin{array}{c}\text { Esplizitoki } \\
\text { adieraziz }\end{array}$} & \multicolumn{2}{c|}{$\begin{array}{c}\text { Esplizitoki } \\
\text { adierazi gabe }\end{array}$} \\
\hline Kop. & $\%$ & Kop. & $\%$ \\
\hline 11 & 64,7 & 6 & 35,29 \\
\hline
\end{tabular}

\section{Eskualdaketetan erabilitako bideak}

\begin{tabular}{|c|c|c|}
\hline \multirow{2}{*}{ Motak } & \multicolumn{2}{|c|}{ Eskualdaketak } \\
\cline { 2 - 3 } & Kopurua & $\%$ \\
\hline Dohaintzak & 13 & 59,09 \\
\hline Testamentuz & 9 & 40,9 \\
\hline
\end{tabular}

Egindako azterketaren ondorioak zehazterakoan baserri bakoitzarekiko analisia sakona egin ordez, Foruaren oinarri gertatzen diren hiru zutabe izan dira atal honen ardatza:

1. Tronkalitatea

2. Oinordekotza

3. Kapitulazioak

Honela bada, aurrez agertzen diren zenbait datu zertxobait gehiago zehaztea dugu helburua. 
Badirudi lanaren haseran egindako hipotesia egiazkoa dela aztertutako transmisio kopuru gehiena Forua bitartekoa delarik egina baita. Portzentaiei begiratuz, \%76,19a legedi hau erabiliz egin dela konturatuko gara; \%23,80a geratuz Legedi Zibilpean egindakoentzat.

Transmisioen datuen inguruan zera esango genuke:

1. Legedi Zibilpean egiten direnak, 1930.urtearen ostekoak dira.

2. Hala ere, data honen geroztik ere agertzen dira Foralpean egindakoak.

3. Badirudi aztertutako kasuak begiratuz, 1959.urtean (Konpilazioaren urtea bideratutako legediak ez zuela berehalako aplikapenik izan guregunean, Allenda eta Eizmendi baserrien transmisioak adierazten duen bezala.

Oinordekoa izendatzerakoan ere gehientsuenak, Bizkaiko Foruak eskainiriko aukera aipatuz, beste anai-arrebak baztertuz jokatzen da.

Oinordekotza, baserriaren iraupena ziurtatuko duen tresna egoki bezala, argi agertu izan zaigu aztertu dugun baserri hauen historian.

Baserri batean gainera bi legedien arteko borrokaren seinalea aurkitu dugu. Honako testu hau izan daiteke egoera honen adierazgarria:

«Según testamento hecho en Ondárroa el 27 de Agosto de 1928, manifiesta que por tratarse de caserío se rige por el Fuero de Vizcaya, por lo que instituye y nombra como única heredera universal a su hija ............. Lega a sus hijas ............... la cantidad de 1.500 pesetas a cada una y aparta y excluye con la legítima foral a sus demás hijos y herederos».

«... por encontrarse el caserío en tierra llana y no rural, por tanto bajo el C. Civil y no Foral, se aplica en esta herencia el Derecho Civil, sobre esta base el testador instituye herederos a sus cuatro hijos, si bien a los tres hijos de la legítima podrían ejercitar la acción ad. suplementaria. Pero como .............. cobró 3.000 pesetas por dote de casamiento y estando de acuerdo los otros dos hijos con sus legítimos, queda adjudicado todo el caserío para ..............»

Sarritan, nahiz eta legediak erabateko erabakia hartu, beste mugimendu batzuen bitartez, xedea betetzen ahalegindu zirenekoa ere azpimarkagarria dela uste dugu. Baserri baten jabetasuna bi edo hiru lagunen artean eman da ere, bat bakarraren eskuan jarri izan zuten, baserria bera momentuko biztanle eta eragileen gainetik baita:

«...lega a su hijo...$\ldots \ldots \ldots$.... los tercios de mejora y libre disposición de su herencia, y designo herederos universales por iguales partes a sus cinco hijos, expresando el deseo de que su esposa goce mientras viva 
de todos los bienes existentes a su fallecimiento y de que a fin de conservar indivisa la explotación...»

Oinordekotza erabakitzen denean, baserrian geratuko denari baldintzak ezartzen zaizkio. Beste nolabaiteko kontratua litzateke zeine$\tan$ (gehienetan) gainontzekoei ordaindu beharreko kopuruak zehazten diren.

«Se adjudican al heredero todos y cada uno de los bienes inventariados y entre ellos la finca, imponiéndole las siguientes condiciones:

a) Satisfacer todos las deudas inventariadas que ascienden a 17.650 pesetas.

b) Abonar a la viuda la dote de 4.000 pesetas y la renta anual de 60 pesetas en pago de la cuota usufructaria.

c) Abonar a cada uno de sus hermanos la cantidad de 1.220 pesetas que por su legítima les corresponde.»

Baserriaren iraupena dela helburu, aztertutako baserri batean eman zen mekanismo bitxi bat ere adierazi nahi dugu:

$\ll$ Los hijos ........ ceden a su medio hermano, hijo de ........ casado con .........., que acepta todos los derechos que a los cedentes corresponden en la herencia de su padre ...........»

Kapitulazioen atalari lotuz eta ezkontz kontratuetan oinarrituz bi alderdi azpimarratuko genituzke:

1. Berauen kopurua. Foralpean egindako transmisioetan, \%70,58an ezkontz kontratuak egin ziren.

2. Kontratu hauen garrantzia baserri horretan bizi izango zirenen arteko harreman ekonomiko juridikoak zehazteko eta baita gainontzeko anai-arrebarekiko loturak arautzeko bai giza mailakoak baita ekonomikoak.

Eskuartean jasoak ditugunak denak ere oso antzekoak izanik, foruari dagokionez, bitarteko honen adierazgarri gisa honako hau jasotzen dugu:

Capitulaciones:

1. El donante se reserva vitaliciamente el usufructo de la mitad de los bienes donados y será necesario su consentimiento para cualquier operación de venta, obras, etc.

2. El donatario habrá de satisfacer a sus hermanos ......... a cada 10.000 pesetas cuando se casen o tomen estado o se decidan 
a salir de la casería para hacer vida independiente. Mientras no tomen estado tendrían derecho a vivir en el caserío.

Don ............ para plena eficacia de la donación aparta y excluye de lo donado a cualquier otro legitimario con lo que atribuye el Fuero de Vizcaya.

Tronkalitateaz bi hitz baino ez ditugu esango, erabili ditugun dokumentu guztietan ezaugarri hau begibistakoa delako.

Hainbat gauza usadioak lege bihurtzen dituela diogu; kasu honetan tronkalitatea betidaniko usadioa izanik, baserriaren iraupenerako tresna praktikoena bilakatu da.

\section{1959. urtetik aurrera}

\subsection{9. urteko Konpilazioa azterketa orokorrean}

\subsubsection{Sarrera gisa}

1959. urtean eta berriro ere Espainiako Foru zuzenbide guztien elkartzeko nahian, Bizkaiko eta Arabako Konpilazioa ageri zen. Testu honen helburua honelakoxea genuen:

«Lan honen helbururik nagusiena, tradizio juridikoaren bilduma ordenatu eta sistematiko baten bidez zein zuzenbide hispaniarren ezaguera, zehaztapen eta komunikazioaren bitartez, Kode Zibil orokor baten azterketa eta idazkuntzara heltzea da, bertan bilduko direlarik herri espainiarrean eta bertako eskualde desberdinetan bizirik dirauten erakunde bizi eta indarrekoak, erro nazionala duten errealitate natural, sozial eta juridikoen erakusleak eta berebiziko interes moral zein materialei dagozkienak. Azken batetan helburua ez da, halanolako zuzenbide uniformea sortzea, erakundeen onartasun eta komenigarritasunari buruz jokatzea baino, nazionala denaren egituraketa eta integrazioaren bidea era amultsu eta zientifiko batez egiteko.»

Dakigunez, Konpilazioa egituratu aurretik, juristen artean ere legedi bikoiztasuna zela eta, bazen iritzi ezberdinik (ikus 10. orrialdea).

Honela, Carlos de la Plazak eta Jadok ${ }^{5}$ egindako planteamendua, hots, «Bizkaia osorako ezin denez lege bakarra egin, lor dezagun lege ba-

5 De la Plaza y Salazar, C. Actas de la Comisión Especial de Codificación de Vizcaya. Estudio de 1899. (26-27. orr.). JADO Y VENTADES, R. «Derecho Civil de Vizcaya». Comenta-

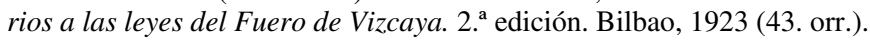


karra herri bakoitzerako», ez zuen Konpilazioak kontutan izan: bai ordea, Gregorio Balpardak aipatua: baserria hartzea foralitatearen gune gisa.

«Horrelako hori konpontzeko, Probintziako Batzordearen Aurreproiektuan bildutako formula proposatu zen, hots, bat-batean zuzenbide arruntaren gunea hiri forugabeetako hiriguneko mugatik, gaur beraien udal mugarteetako perimetroa zehazten duen lerro administratiboraino zabaltzea. Sistema honen bidez, Foru Zuzenbideak, trukaketa astunenaren ordainez, itxura bateko egonkortasuna irabaziko luke: hau da, bizkaitar familia ondarearen berezitasunik jatorrizkoenak eta bereziz kokatzen direneko baserrigune zabal askotatik kanpo geratzea.»

\subsubsection{9. urteko Konpilazioa}

Abiapuntu gisa, Konpilazioak bere 2. artikuluan adierazten duena ezagutu beharrekoa dela iruditzen zaigu, aztertzen ari garen «hirian» aplikatu beharreko legedia argi zehazten baitigu:

2. artikulua. Bizkaiko Infanzonatu edo Lur Lauaren izenduraz gaur egungo Bizkaiko probintziak hartzen duen lurralde osoan izendatzen da, salbu Bermeo, Durango, Ermua, Gernika eta Lumo, Lanestosa, Lekeitio, Markina, Otxandio, Ondarroa, Portugalete, Plentzia eta Balmaseda, hamabi hiriak, Urduñako ziutatea eta Bilboko udal mugarte osoa.

Salbuetsitako lurralde honetan Kode Zibila izango da aginduzko.

Honela bada, gure «hirian» beste hainbatetan bezala, Kode Zibila litzateke indarrean jarri beharrekoa.

Komenigarria zaigu ere, legedi honek (Konpilazioak) bere 3. artikuluaren bitartez «hiri» hitzez zer ulertzen duen jakitea:

3. artikulua. Aurreko artikuluan zerrendatutako hamabi hiri forugabeei dagokien izendurak beraien hiriguneetako egungo edo etorkizuneko perimetroko lurralde osoa hartzen du barru.

Beraz, hiri forugabeetako hiriguneen alboko soro-landa eta lurrak beraiei erantsitzat joko dira, Kode Zibila izango dutelarik aplikatu beharreko legedia, baserri bateko atalak izanik, nekazal ustiategiaren batasunari lotuak ez badira behintzat.

Artikulu honekin bukatzeko, adieraz ditzagun ere Kode Zibilpean geratuko liratekeen beste hirigune inguruko zenbait lur:

a) Beraien udal mugarteetan kokaturiko eraikuntza eta lurguneak, ustiategi industrialera zein berez baserriko erabilera edo ekintza 
ez direnetara zuzendutakoak edo eta baserri bateko lur sailak ez direnak.

b) Egungo nahiz etorkizuneko lurzoruaren gaineko legeriaren arabera, ofizialki onartutako urbanizazio planek joak izanik, beraien udal mugartean lekuturiko lurguneak.

Ezin dugu ahaztu, lege bikoiztasun honek sortzen duen arazo nagusienetariko bat: hirigunea handituz doan heinean, berton aplikatzen den legea ere hedatuz doa, forudun lurrak zirenak Kode Zibilpekoak bihurtuz.

Egoera hau Konpilazioan argi azaltzen zaigu:

«..., zeren jatorrian Zuzenbide arrunta hiri forugabeetako udal mugarte hiritarrean kontzentratua egonik, inguruko baserri giroan hiritarren izaera tartekatzearen prozesu geldoak Kodearen eta Foruaren arteko gatazka automatikoa sortzen du, etengabeki onibarren oinetxekotasun objetiboa zein forudunen oinordetzazko estatutu pertsonala eta ezkontz ekonomia nahasten dituelarik».

eta baita:

«Horrela zehaztapen juridiko falta hori sortzen indar desbideratzaile handiagoz lagundu du honako errakuntza historiko honek: hau da zuzenbide pribatua, Forua hiri forugabeen zabalkunde Administratiboak bereganaturiko baserri guneetatik baztertuz, aldaketa topografikoen menpean jartzeak.»

Nahiz eta Konpilazioaren 4. artikuluak zera dioen:

4. artikulua. Bizkaiko udal mugarteetako mugen aldaketa administratiboek ez dute lurralde ukituei dagokien zuzenbide zibil aplikagarria aldaeraziko.

Konpilazioaren inguruan egin dugun gainbegirada bukatzeko argi ikusten dugu (3. artikuluari begiratuz) lurralde osoan aplikatu beharreko legea Kode Zibila dela, ez badira behintzat baserri bati atxikitutako lurrak; egoera honetan, Forua aplikatuko litzateke.

Beraz, Forua aplikatu ahal izateko, aurrez aipatu egoera demostratu beharra legoke, bestela lege orokorra sartuko litzateke indarrean.

Bizkaian beraz, Konpilazio hau dela bide, legedi zibilaren aldetik, lur banaketa hirukoitza ematen da, 2., 3. ta 4. artikuluen arabera:

a) Kode Zibila goitik behera aplikatzen den lurraldea: Bilbo. 
b) Bikoiztasundun lurraldeak: Bermeo, Durango, Ermua, Gernika eta Luno, Lanestosa, Lekeitio, Markina, Otxandiano, Ondarroa, Portugalete, Plentzia, Balmaseda eta Orduñako hiria.

c) Lurralde aforatuak: beste guztiak.

Eta ondorenez:

«Los caseríos y zonas rurales de Lequeitio, Ondárroa, Durango, Ermua, Valmaseda, Portugalete, Lanestosa y la ciudad de Orduña quedan sometidos al Fuero — si bien en supuestos muy problemáticos- cuando hasta entonces sólo regía el C.C.»

Ikusi dugun bezalaxe, datuek beste zerbait adierazi digute.

\subsection{Konpilazioa Ondarroari lotuta}

\subsubsection{Hirugunearen zehaztea}

Gogoan izanda Konpilazioa 1959. urtekoa dela, urte horretan edo parekoren batean Ondarroako hirigunearen zehazteari ekin genion.

Eskuan erabili izan dugun mapan, 1957. urtekoa (1. irudia), hiriaren nondik-norakoa erabat zehazturik geratzen da, beste hainbat lurralde ondorengo urteetan (Berriatuaren anexioa dela eta) Ondarroako zati izatera pasatuko direlarik: Magdalena eta Asterrika.

Hirigunearen perimetroa, Konpilazioa indarrean sartu baino bi urte aurretik, lehenengo mapak adierazten digu.

Gehiago zehaztea alderdi honetatik zaila gertatuz, baserrigunea zehazteak, zeharka, hirigunearen zehaztapena eragingo du.

\subsubsection{Baserrigunearen zehaztea}

Augustin Zubikaraik bere «Baserri Giroan» (Ondarroa) liburuan azaldu moduan: gaur, eta len, Ondarroak ba daukaz bere baserriak.

Aipatu behar ere gure inguruko baserri batzuk bizitza bikoitza dutela, herri legea alde batetik eta eleizaren lotuerak bestetik.

Baserrigunearen zehazte lanean Augustinen aipatu liburua izan dugu iparra eta bere aurkezpenean egiten duen hausnarketa gureganatzen dugu:

«Inguruko baserriei ikututen dautsegu. Ondarroaren inguruan direnei eta erri onegaz era bateko edo besteko lotuera daukenei jaubetasun eskubiderik iñori kendu edo ukatu barik.» 


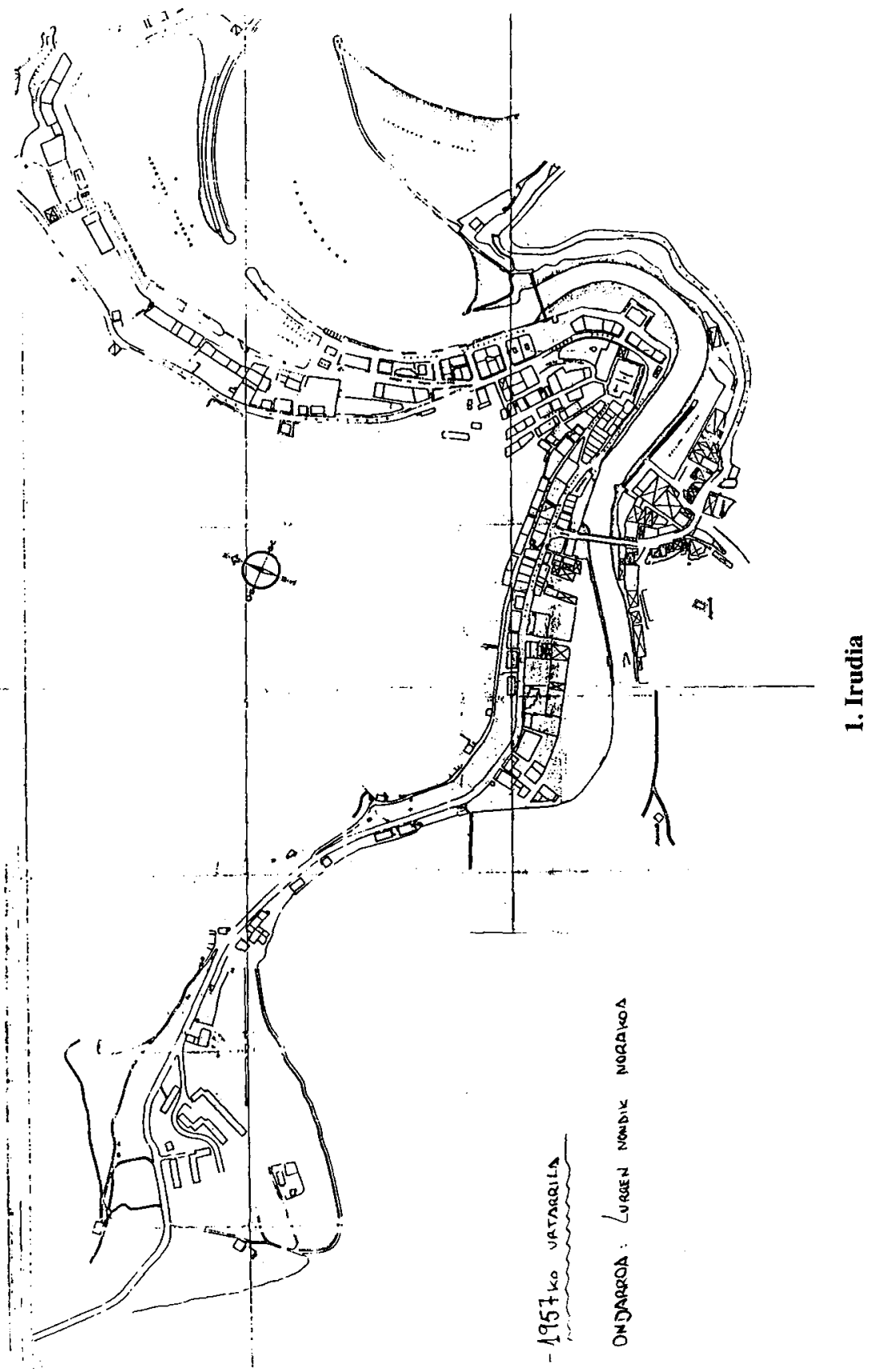


Mereludi inguruko baserriak (Miloi gainekoak) ez ditugu aipatuko 1984. urtean eman zen Berriatuaren desanexioa bide delarik, elizate honen ardurapera pasatu baitziren.

Hiru auzo nagusitan bana daiteke Ondarroa: Asterrika, Errenderi eta Gorozika eta auzoz-auzo gure gune baserritarra era honetara lekutuko genuke:

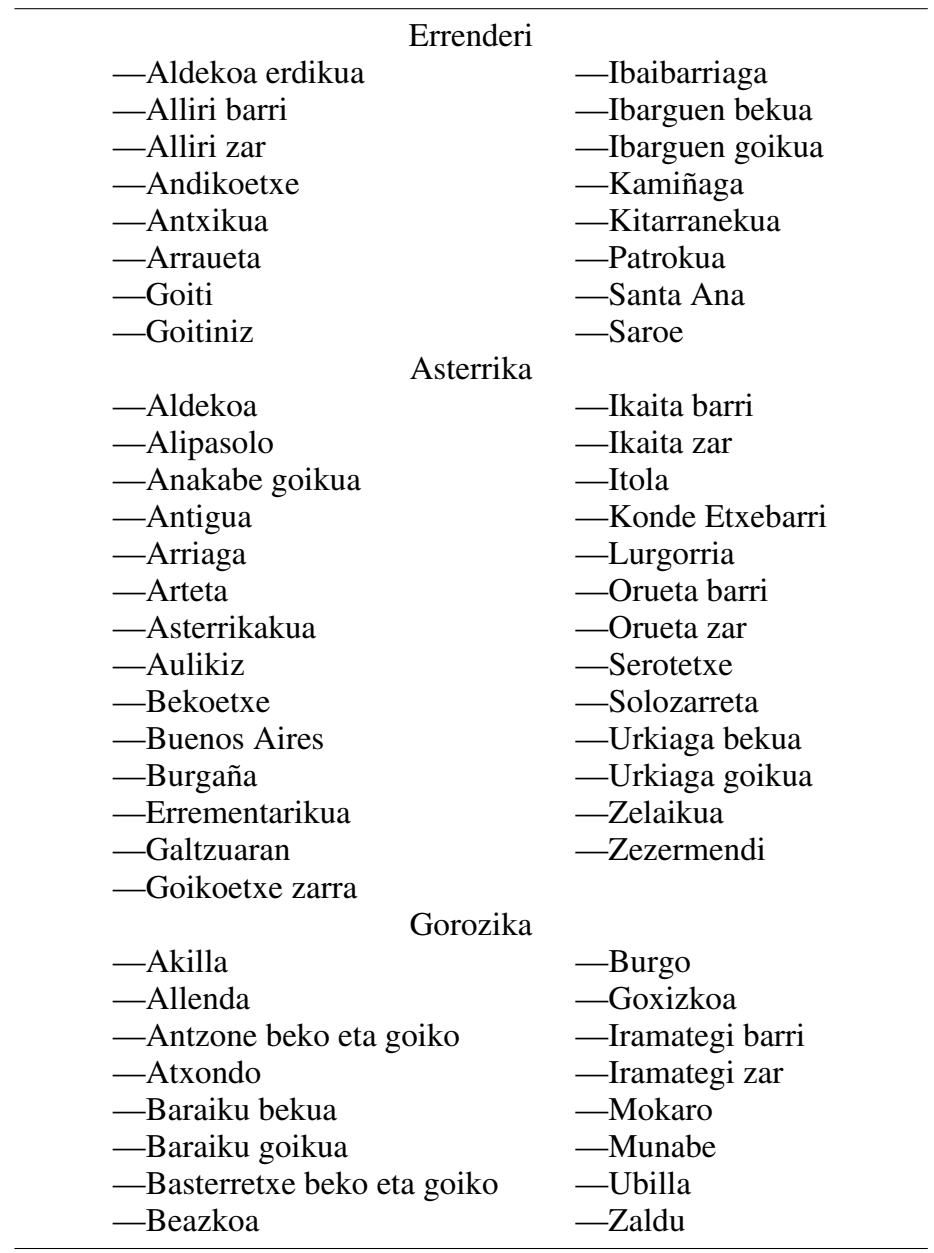

Honako hauek izango lirateke teorikoki bederen Konpilazioaren arabera foralpekoak diren lur ondarrutarrak. 


\subsection{Berriatuaren anexioa eta beronen eragina}

Martxoaren 27ko 655/1969 dekretuak adierazi bezala6, Ondarroako hiriari, Berriatuako elizatea lotzen zaio (2. irudia).

Berriatuaren atxikitze honek legedi aldetik zer nolako eraginak izan zituen aztertu aurretik, egokia gerta daiteke, 1967ko urriaren 10ean Ondarroako udaletxeko idazki batean azaltzen denez anexio honen zergatiak adieraztea.

«... y en representación de la Corporación que presido, me persono en el expediente de referencia manifestando la total y absoluta conformidad del Ayuntamiento de Ondárroa para que proceda a incorporar al mismo el de Berriatúa, por estimar como se intentará demostrar con el presente escrito, que la única solución viable para el desarrollo presente y futuro de ambas poblaciones.

Desde el punto de vista de Ondárroa por precisar mayor base territorial para asentar su próspera industria, en su mayor parte derivada de la

6 Decreto 655/1969 de 27 de marzo por el que se aprueba la incorporación del municipio de Berriatúa al de Ondárroa en la provincia de Vizcaya. Por Resolución del Gobernador Civil de Vizcaya convalidada posteriormente por el Ministerio de Gobernación, se acordó iniciar, de oficio, expediente para la incorporación del Municipio de Berriatúa al de Ondárroa.

Tramitado el expediente con sujeción a las normas de procedimiento contenidas en la Ley de Régimen Local y en el Reglamento de Población y Demarcación Territorial de las Entidades Locales, el Ayuntamiento de Berriatúa acordó, con el «quórum» legal, oponerse a la incorporación y el Ayuntamiento de Ondárroa acordó, con el mismo «quórum» aceptarla.

Han emitido informes favorables a la incorporación las Jefaturas de los Servicios Provinciales consultados, así como la Diputación y el Gobernador Civil; acreditándose la confusión de edificaciones del barrio de la Magdalena, del Municipio de Berriatúa, con el núcleo urbano de Ondárroa, en cuyo barrio el Ayuntamiento de Ondárroa viene prestando los servicios municipales. Igualmente se acreditan las limitaciones económicas que pesan sobre el Municipio de Berriatúa para atender sus obligaciones mínimas, a diferencia de lo que ocurre con el de Ondárroa, cuyos medios personales y materiales se bastan para atender a sus propios servicios y además para establecer los que ahora faltan en el Municipio de Berriatúa. Por ello se aprecia la existencia de los notorios motivos de necesidad o conveniencia económica o administrativa exigida por el artículo catorce, en relación con el apartado c) del artículo trece de la Ley de Régimen Local, para que se pueda acordar la incorporación de un municipio a otro.

En su virtud, de conformidad con el dictamen emitido, por mayoría, por la Comisión Permanente del Consejo de Estado, a propuesta del Ministro de la Gobernación y previa deliberación del Consejo de Ministros en su reunión del día veintiuno de marzo de mil novecientos sesenta y nueve.

Dispongo:

Artículo primero.-Se aprueba la incorporación del municipio de Berriatúa al de Ondárroa, en la provincia de Vizcaya.

Artículo segundo.—Queda facultado el Ministerio de la Gobernación para dictar las disposiciones que puediera exigir en cumplimiento de este Decreto.

Así lo dispongo por el presente Decreto, dado en Madrid a veintisiete de marzo de mil novecientos sesenta y nueve.

El Ministro de la Gobernación, Camilo Alonso Vega.

Francisco Franco. 


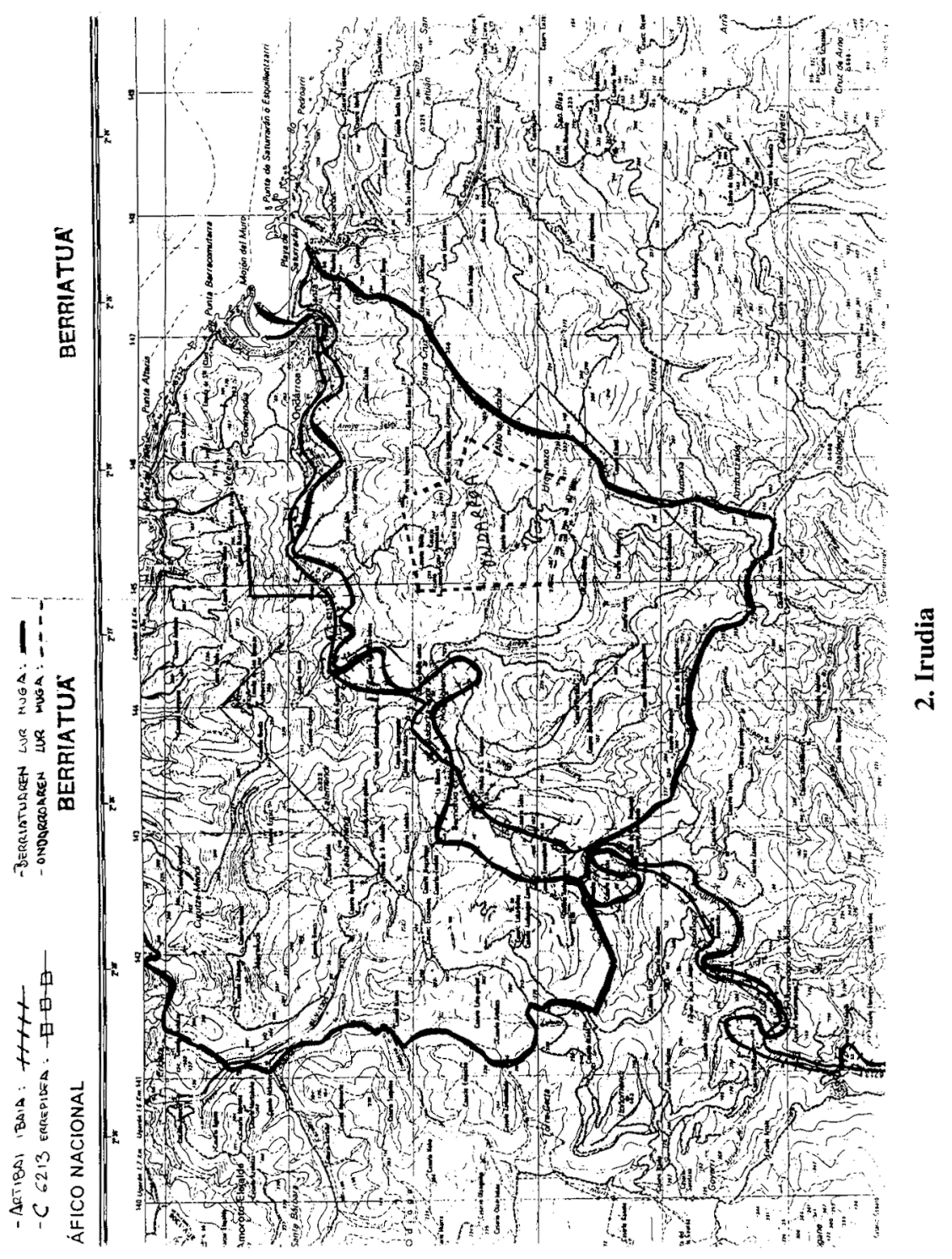


pesca y planificar, con un criterio racional, la ordenación de las distintas zonas urbanas, industriales y rurales. Por lo que respecta al Municipio de Berriatúa, su necesidad de que se lleve a efecto la incorporación municipal proyectada, queda plenamente justificada por ser ésta la única solución posible para la creación de una serie de servicios públicos municipales que solamente podrán ser prestados por el Ayuntamiento de Ondárroa, ya que la organización y la capacidad económica de esta última Corporación municipal le permiten hacer frente a problemas que el Ayuntamiento de Berriatúa, precisamente por carecer de dichos atributos, se halla totalmente imposibilitada de prestar a sus vecinos». (10 de octubre de 1967).

Asmo hauek zirela medio, Ondarroako udaletxeak Berriatuaren anexiorako oinarri batzuk proposatu zituen denen artean azter zitzaten.

Eskuartean dugun lanari lotua agertzen zaigu oinarri hauetako i) puntua (ikus 2. eraskina) zeinak zera zioen:

i) De conformidad con lo dispuesto en el artículo 4 de la Ley de 30 de julio de 1959, aprobatoria de la Compilación del Derecho Civil de Vizcaya y Alava, las modificaciones administrativas que se produjeran como consecuencia de la incorporación municipal proyectada, no alterarán el derecho civil aplicable al territorio afectado. Es decir en Berriatúa seguirá rigiendo la Compilación del Derecho Foral de Vizcaya y en Ondárroa el Derecho Común?

Honela bada, 1967ko abenduaren 11ko bilerako aktak argi adierazten digu zein izan zen lehenengo asmoa aplika beharreko legediaz.

Dena den eta bitartean gertaturikoa alde batera utziz (ez baita gure lana oraingoan sortu zen prozesua aztertzea) 1974ko maiatzaren $17 \mathrm{ko}$ akta irakurriz (Berriatuaren anexioa dela eta hartu beharreko neurriak) konturatuko gara 7 urte aurretik planteiatzen ziren puntu batzuk desagertu direla beste batzuk sartuz.

Desagertutako puntu bat, goian aipatu dugun i) puntua da, hain zuzen ere, anexio akordioan Berriatuan aplikatuko den lege zibilari buruz ez delarik ezer agertzen.

Agian akordio honen 4. puntuak zerbait adieraz diezaguke:

Cuarto.-Que una vez obtenido, en su caso, la preceptiva autorización de la Superioridad para crear un nuevo Distrito en Ondárroa se nombrará Teniente de Alcalde en tal Distrito a un miembro de la representación del extinto Municipio de Berriatúa.

\footnotetext{
7 Acta del día 11-12-1967 de la M.N y M.L. Villa de Ondárroa.
} 
Ulertzen dugunez, Berriatua Ondarroaren zati («distrito») izatera pasatuko litzateke automatikoki kontrako akordiorik ezean, Kode zibila aplikatuko litzaiokeelarik ziurasko.

Hau, dudarik gabe, Konpilazioaren 4. artikuluaren aurka letorke, muga administratiboen aldakuntzak, lur hauetan aplikatu beharreko legediaren aldaketa ekarri baitzuen.

Anexio honetako 3. artikuluak ere berebiziko garrantzia hartzen du:

Tercero.- Interesar de la Superioridad la creación de un nuevo Distrito en Ondárroa, que corresponderá al actual y extinto Municipio de Berriatúa, con la excepción de los Barrios de la Magdalena y Asterrica, que se incorporarán automáticamente a los Distritos correspondientes de Ondárroa.

Hau ikusirik, Konpilazioaren 3. artikulua Magdalena eta Asterrikan (administratiboki eta zibil arloan) praktikan erabat gailentzen dela esan dezakegu, hirigunearen perimetroa hedatzeak, Kode Zibilaren aplikazioa gunea zabaldu baitzuen. Hedatze honek, hirigunean aplikatzen den legediaren zabaltzea dakar berarekin kasu honetan eta Magdalena, Txori Erreka eta San Juan Txurru auzoetan Kode zibila aplikatzen zen (anexio aurretik ere) hirigunearen zati bezala kontsideratuak baitzeuden nahiz eta berez, lurralde aforatuak izan.

Distritu hauek egiteak, foraltasunaren galera nabaria ekarri zuen berarekin. Ataltxo hau ixteko zera esan behar konklusio gisa:

«Anexioarekin (legedi aldetik) Foruak atzera pausu berri bat eman zuen Kode zibilak esparru berriak irabaziz, eta are gehiago, praktikan Kode zibilak Foruari hainbat gune janak zituela aspaldi nahiz eta legalki beste gauza bat aginduta egon.»

\subsection{Berriatuaren desanexioa eta beronen eragina}

1983ko azaroan, Berriatuaren desanexioa eman zen bi herrion arteko mugak birdefinitu zirelarik (3. irudia).

Agertu legez ${ }^{8}$, ontzat eman zen adierazten den akordioa, berriz ere elizate izatera bihurtuz.

8 Primero.-Ratificar las modificaciones de límites y compromiso de recogida gratuita de basura por un período de 5 años, propuestos por los partidos políticos que componen el Ayuntamiento de Ondárroa, y aprobados por el Consejo Gestor de Berriatúa, en sesión de 3 de diciembre de 1982.

Segundo.-Acordar la segregación de Ondárroa, a consecuencia de la cual, renace la Anteiglesia de Berriatúa, adoptada con el «quórum» exigido por el artículo 3 de la Ley 40/81 de 28 


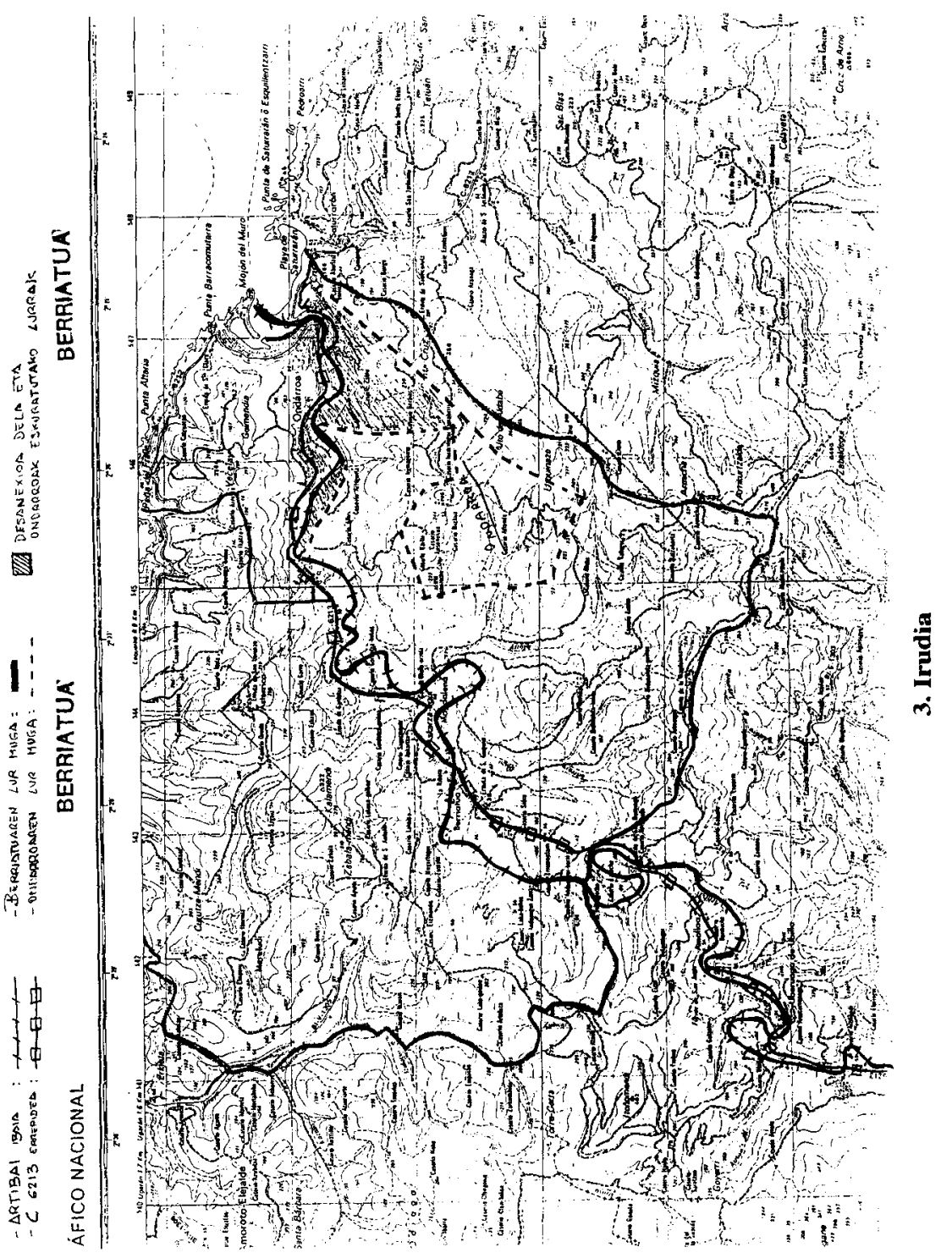


Akta hau irakurri ondoren (17-12-1982), laster konturatuko gara aplikatu beharreko legediaz ez dela ezer adierazten.

«Eizmendi» inguruko baserriak Berriatua izatera pasatzen dira eta Magdalena auzoko etxebizitza eta lurrak aldiz, Ondarroa izatera datoz.

Límites territoriales señalados por la Comisión de Berriatúa, a efectos de segregación:

Tercero.-Los límites territoriales anteriores a la anexión que mantenían la Anteiglesia de Berriatúa y la Villa de Ondárroa, sufren las siguientes alteraciones o variaciones:

a) Pasan a pertenecer al territorio del municipio de Berriatúa, los 3 caseríos de «Eizmendi» y sus pertenecidos, ubicados en el Barrio de Mereludi, que lo eran del municipio de Ondárroa.

b) Por el contrario, pasan a pertenecer al territorio del municipio de Ondárroa, las viviendas y terrenos del municipio de Berriatúa, en el Barrio de Magdalena, comprendidos entre la «línea divisoria UNO» y «línea divisoria DOS», y que a continuación se especifican.

Honela, desanexioa ematen denean, hots, Magdalena Ondarroaren zati denean, Kode zibila berton aplikatzen jarraituko da.

Foruak auzo honetan, duela denbora asko galdu zuen eskutik zeukan protagonismoa eta desanexio prozesu honek esan dezakegu, ez duela inolako berezitasunik eskaintzen Kode zibilaren aplikazioa erabatekoa baitzen aurretik.

Anexioari buruzko puntuan adierazitakoa Konpilazioaren 3. artikuluaren inguruan baliogarri gerta daiteke kasu honetan ere.

Arazo hau (Foruaren galtzea, Kode zibilaren alde zenbait lurralde aforatutan) Ondarroan ezezik beste hainbat herritan ere eman dela ikusiz, ia nahigabe eta zuzen zuzen «Euskal Herriko Foru Zibil Berrira»9 eramaten gaitu, zeinak foru lege errealitate berri bat eskaini nahi duen sortu eta konpondu gabeko hainbat arazoekiko (guk eskuartean darabilguna barne).

de octubre, con los límites territoriales expuestos en los antecedentes del presente acuerdo, acompañándose al efecto, los documentos exigidos por el artículo 20.2 del Reglamento de Población y Demarcación Territorial, y que quedan unidos al presente acuerdo.

Tercero.-Someter a exposición pública, por espacio de 30 días, el acuerdo de segregación y documentación anexa, de conformidad con lo dispuesto en el artículo 15 del Reglamento de Población y Demarcación Territorial.

Y para que conste, extiendo la presente, visada y sellada, en Ondárroa, a veinte de diciembre de mil novecientos ochenta y dos.

9 Eusko JaURlaritZa. Euskal Herriko Foru Zuzenbide Zibilari buruzko legea. 1992. 


\section{4. «Euskal Herriko Foru-Zuzenbide Zibila» (1992)}

Euskal Herriko egoerari hobeto erantzun eta legedia ere XIX. eta Xx. mendeetako aurrerakuntzei lotu nahian sortutako legea dugu hau.

«Foru-jaurpidea gain-behera joan izanak galerazi egin zion gure araudi zibilari legegintza-teknikak XIX eta XX. mendeetan egindako aurrerapide sakonekin batera joatea eta, horregatik, Foru-Zuzenbideak berez dituen balio nabarmenak aintzinako moldez jantzita agertzen dira oraindik, moldeok eguneratzea beharrezkoa dela...»

1992ko uztailaren 1ean onarturiko lege honek besteak beste, arestian Konpilazioak bere 2., 3. eta 4. artikuluez sorturiko nahastea konpontzea nahiko luke beronen I. idazpuruan, Ezarpen-Eremuan adierazi bezala:

«1959. urteko Bildumak nahaste handiagoa sortu zuen bere 2. eta 3. ataletako arau marapilotsuekin, eta harrez gero zail egiten da, Hiriguneetatik kanpo, zor den foruduna eta nor ez zehaztea.»

Adrian Celayak ${ }^{10}$, hirien lurrak zehazterakoan sortutako arazoa, gune aforatu eta ez aforatua zer den zehazte gabean datzala dio:

«El problema de delimitación territorial de las villas está, según lo expuesto, en la determinación de la zona aforada y la no aforada.»

Legedi zibil orokorraren lur jabetze prozesu etengabea eragoztea ere izan da lege honen helburua:

«Gainera, Bildumaren sistemak alde forudunen eta forugabekoen lurraldeak behin eta berriro aldatzen ditu. Hori dela eta, eta Konstituzioaren 9.3 atalak eskatzen duen segurtasun juridikoa aintzakotzat hartuta, arau zehatzagoak egin beharra dago. Erizpide hau erabili da Foru-Lege honen 6, 7 eta 8. atalak eta Azken Erabakietako lehenengoa idaztean, AutonomiaEstatutuaren 10. atalean aitortutako legegintzarako baimenean oinarritzen direla eta forudun lurraldea zein den ondo zehaztuta utzi nahi dutela.»

Dena den eta Celayaren iritziz ${ }^{11}$ Kode zibilaren aplikazio gunea urteen poderioz zehazten joan da, gehienbat jarraiko lau zergatiren erruz:

a) En la mayor parte de las villas, el Fuero se siguió aplicando en la zona rural. De hecho, los términos que se fijaron en las villas eran muy am-

10 Celaya Ibarra, A. Derecho Civil Vasco. Edit. Universidad de Deusto, Bilbao, 1993.

11 Celaya Ibarra, A. Derecho Civil Vasco. Edit. Universidad de Deusto, Bilbao, 1993 (73. orr.). 
plios y normalmente llegaban hasta las villas vecinas, pero la ley común no se aplicaba sino en los núcleos urbanos y las anteiglesias siguieron manteniendo sus usos y costumbres. Así podía decir Jado que «las villas generalmente con muy pocas excepciones se rigen en la parte urbana por el derecho común y las anteiglesias y parte rural de las villas por el Derecho foral».

b) Dentro del casco de la villa existían muchas casas que debían pagar un censo al Señor, y para ellas se promulgó por los Reyes Católicos la Real Provisión de 17 de marzo de 1484 ordenando aplicar ciertas normas forales, lo que, de hecho determinó a estas casas a la aplicación plena de las leyes forales. La consecuencia fue que en algunas villas se hacía muy difícil distinguir la zona aforada de la no aforada (Larrabezúa, Munguía, Miravalles y Rigoitia) terminando por aplicarse exclusivamente el Fuero.

c) La Concordia de 1630 permitió a las villas optar por la aplicación en su término de la ley civil de Vizcaya y acogiéndose a esta disposición adquirieron la foralidad la villas de Elorrio (1712), Ochandiano (1818), Bermeo (1734) y Villaro (1825).

d) Se produjeron numerosas anexiones y segregaciones de anteiglesias y villas que suscitaron dudas sobre la ley vigente en los nuevos términos que se formaban (Markina-Xemein, Arbacegui-Guerricaiz, Gernica y Luno, etc...).

Uztailaren 1ean onartutako legeak bere 7., 8. eta 9. artikuluen bitartez, Konpilazioak bere 2., 3. eta 4. artikuluetan erabat definitzea lortu ez zuena bideratu nahi du. Hirigunearen perimetroa eta ondoren eman daitezkeen aldaketak zehazki adierazten dizkigu:

7. atala. Aurreko atalean aipatutako lurralde forugabeko hiri bakoitzaren jatorrizko hirigunearen gaurregungo lurrak eta Foru hau indarrean sar dadinean indarreko hirigintza-planen arauera «hirilur» bezala sailkatuta egon daitezen bere albokoek osatuko dute.

Eta baita erabaki gehigarri baten bidez ere:

\section{Erabaki gehigarria}

7. atalean ezarritakoaren ondorioetarako, forurik gabeko Bizkaiko Hirietako Udalek Lege hau argitaratzen denetik hiru hilabeteko epea dute jatorrizko hirigunearen gaur eguneko lurrak eta indarreko hirigintza-planen arauera «hirilur» bezala sailkatuta egon daitezen bere albokoak zehaztuko dituen planoa egiteko.

Hain beldurgarria gertatzen zen egoera, hots, Kode zibilak Foruari lur kentzea, ezen 8. artikuluaren bitartez erabat geldiarazten dela:

8. atala. Hirigintza-planen osteragoko aldaketek ez dute aldaeraziko lurralde forugabekoaren luze-zabalera. 
Eta 9. artikulua Konpilazioaren 4. artikuluarekin parekatzen badugu, desberdintasun nabari bat duela konturatuko gara: desanexio egoera kontutan hartzen du.

9. atala. Administrazioak egindako Bizkaiko udalen muga-aldaketek ez dute aldaeraziko lurraldeotan ezarri beharreko Zuzenbide Zibila.

Hirien bati erantsirik dagoen aintzina Elizate, izandakoren bat Hiri horretatik bananduko balitz, berez eta besterik gabe berreskuratuko leku zeukan jatorrizko elizate-izaera.

Honela bada, zilegi bekigu, Celayak ${ }^{12}$ adierazitakoa bergogoratzea:

«... la ley vasca de 1 de julio de 1992 haya decidido no cambiar drásticamente la condición jurídica de ningún vizcaíno y mantener la situación actual, pero eliminando todos los motivos de inseguridad. El territorio foral queda definido...»

Hala ere badugu oraindik legedi honetan azpimarratu beharreko artikulu bat.

Gailendurik hirietan Kode zibila eta baserri guneetan Forua aplikatzen zela adierazten duen dikotomia, aukera berri bat azaltzen zaie Kode zibilpeko diren «hiriei» hau da, Forua eurei ere aplikatzeko eskabidea burutzea.

Gogo hau gauzatzeko bitartekoak Euskal Herriko Foru Zuzenbide Zibilari buruzko legearen 10. atalean adierazten dira:

10. atala. Legeria zibil orokorra ezargarri duten udalerriek Foru zibil hau euren lurralde guztian ezar dadin aukera egin ahal izango dute, 1630.eko Konkordiaren indarrez eta Konstituzioaren erabaki gehigarrietako lehenengoan eta Euskal Herriko Autonomia-Estatutuaren 10.5. atalean agintzen denaren arauera, honakook betez gero:

a) Udalbatzarraren erabakia, aurkako baino aldeko botu gehiagoz.

b) Bizkaiko Batzar Nagusien iritzia entzutea.

c) Herritarrek onartzea, Udalak deitutako erreferendumean emandako botu baliodunen gehiengoa aldeko izanda.

d) Eusko Legebiltzarraren lege bidez onartzea.

2. Asmo horrek aurrera egingo ez balu, bost urtegarrenera arte ezingo litzaioke berriro ekin.

Argi agertzen denez, edozein hirik egin dezake Foruaren aldeko apostua legearen azterketan adierazi moduan, Forua «eskubide historiko» bezala eskuratzea denon lana izanik.

12 Celaya Ibarra, A. Derecho Civil Vasco. Edit. Universidad de Deusto, Bilbao, 1993 (74. orr.). 


\section{Ondorioak}

Lan honetan zehar, Euskal Herrian eta gure herrian Ondarroan zehazki eman den lege bikoiztasuna aztertzen saiatu gara. Bi legedi sortzearen arrazoi historikoak eta beronen eragina adieraztea xede genuelarik, hain korapilatsua den gai honen inguruan argi izpi bat eskaintzea izan da gure asmorik umilena.

Erabili izan ditugun datuak, lanaren helburuan adierazten genuen hipotesia baieztatu dute eta honela badakigu Ondarroaren hirigunean Kode zibila aplikatzen zela eta dela, baina herri honen gune baserritarrean betidanik Forua izan dela nagusi, gaur egun gertatzen den modu berberean.

Beraz, aztertutako baserrien historia juridikoek diotena hauxe izanik, bagenuen ere beste asmo bat, egoera guztiz garrantzitsu bati lotua hain zuzen ere:

«Hirigunearen hazteak, Kode zibilaren hedatzea suposatzen du, aurretik lur aforatuak zirenetan, beste legedi bat aplikatzen zelarik praktikan.»

Gertaera honen inguruan ere hainbat datu, bai orokorrean eta baita Ondarroaren kasuan ere eskaini ditugulakoan gaude. Ezin dugu ahaztu Magdalena auzoarekin gertatutakoa erabat loturik agertzen zaigula aipatu arazoarekin.

Honela 1959.urteko Konpilazioan eta 1992ko uztailaren leko Euskal Herriko Foru-Zuzenbide Zibilari buruzko legeetan oinarrituz (eta beste hainbat juristen idazkietan) Euskal Herriko foru zuzenbidean sorturiko arazo honi eman dioten tratamendua ere hor dugu azaldua.

Luzeegi gerta aurretik, guzti hau aztertu ondoren, gure azterketaren ondorioak nagusiki lau direla esango genuke:

1. Bizkaiko hirietan eta Ondarroan ere eman izan den legedi bikoiztasuna, batez ere zuzenbide pribatuan, historian zehar eta gaur arte nabaria da.

2. Hiri hauen baserri guneetan (Ondarroan ere) legedi forala aplikatu izan da praktika etengabe baten bidez, idazle batzuek azalduriko iritziaren kontra.

3. Hiri hauen perimetroak ez zehazteak Foruaren aplikazio guneen murriztea suposatu du Ondarroan ere (Berriatuako anexio eta desanexioaren kasuan).

4. $1992 k o$ uztailaren leko legeak, mundu foralari nolabaiteko baikortasuna ekar diezaioke, aurreko zenbait errurentzat irtenbideak definitzen baititu.

Bukatzeko ezin ahaztu gurea bezalako «hirioi» lege berri honek eskaintzen digun aukera, hots, 10. artikuluan esandakoan oinarritu eta lurralde aforatuetan aplikatzen den legedia, guri ere aplikatu ahal izatea. 
Foruaren alde egin dezakegu apostua eta agian hemendik urte batzuetara eskubide honez baliatuz, aukera genuke gure harremanak legedi honen bitartez arautuak izateko.

Horretarako azken lege oztopoa, alegia, Madrileko gobernuak lege honen artikulu batzuren aurka jarritako errekurtsoa (hirien Foru Zuzenbidearen aldeko aukera barne) erretiratua izan da 1993. urteko abenduaren batean Auzitegi Konstituzionalak jaso duenez.

Nork daki urte batzu barru Ondarroak, María Díaz de Harok sorturiko «hiri» honek, Lizarran 1327an jasotako «Carta Puebla» delakoa Bizkaiko Foruarengatik aldatuko duen!!

\section{Bibliografia}

Plaza y Salazar, C. Actas de la Comisión Especial de Codificación de Vizcaya. Ejemplar ofrecido al I. Colegio de Bilbao. (85-97 orr.).

Plaza y Salazar C. Territorios sometidos al Fuero de Vizcaya en lo civil dentro y fuera del Señorío de aquel nombre. Imprenta de M. Echevarría. Bilbao, Año de 1895. (81-92. orr.)

JADO Y Ventades, R. Comentarios a las leyes del Fuero de Vizcaya. (2. ${ }^{a}$ edición). Imprenta y Encuadernacion de la Casa de Misericordia. Bilbao, 1923. (10-44. orr.).

Celaya Ibarra, A. Comentarios al Código Civil y Compilaciones Forales. Tomo XXVI (Compilación de Vizcaya y Alava). Editorial Revista de Derecho Privado (26-61. orr.).

Celaya Ibarra, A. Derecho Civil Vasco. Editorial Universidad de Deusto. Bilbao, 1993. (71-77. orr.).

Urrutia, A. Euskara Legebidean. Editorial Universidad de Deusto. Bilbao, 1990.

EusKo JAURLARITZA. Euskal Herriko Foru-Zuzenbide Zibilari buruzko legea. 1992. ZubikARIAI, A./JuAn FDEZ. EgIGUREn. Ondarroa Baserri giroan. Ondarroa, 1985.

ZubikARIAI, A./JuAn FdeZ. Egiguren. Berriatua. Ondarroa, 1986.

Bizkaiko Egunkari Ofiziala. 170. zenbakia. Bizkaiko Diputazioa. 1993, uztailak 26.

Bizkaiko BatZar NAGUSiaK. Norma Foral 2/87 Reguladora de las Demarcaciones Municipales de Bizkaia. (1987ko otsailaren 20ko Bizkaiko Egunkari Ofizialaren eraskina).

ItURRIZA y Zabala. Historia general de Vizcaya y epítome de Las Encartaciones. (247-251. orr.). 